\title{
Design of Impeller for Centrifugal Compressor
}

\author{
Cho Nwe Tun \\ Lecturer \\ Department of Mechanical \\ Engineering, \\ Technological University \\ (Thanlyin), \\ Yangon, Myanmar
}

\author{
Khin Swe Swe Latt \\ Lecturer \\ Department of Mechanical \\ Engineering, \\ Technological University \\ (Thanlyin), \\ Yangon, Myanmar
}

\author{
May Kyi Tha \\ Lecturer \\ Department of Mechanical \\ Engineering, \\ Technological University \\ (Thanlyin), \\ Yangon, Myanmar
}

\begin{abstract}
This compressor is a dynamic compress which depends on a rotating impeller to compress the air. Impeller is the most important part of the centrifugal compressor components. Detail design calculation of centrifugal compressor impeller is described in this research. This study contains a complete set of detail drawing for blade profile of impeller. It can be used at sites which flow rate is $0.1275 \mathrm{~m}^{3} / \mathrm{s}$ and $45561 \mathrm{rpm}$. The required data are collected from Ahlone Power Station which is located in Yangon. For the given capacity, the inlet and outlet diameter are $0.054 \mathrm{~m}$ and $0.17 \mathrm{~m}$ and the number of blade is 19 .
\end{abstract}

Keywords: Impeller, Pressure, velocity, centrifugal compressor

\section{INTRODUCTION}

Centrifugal compressor is one of the oldest turbo machinery, widely used in various industries like, aviation, oil and gas, refrigeration, etc. Centrifugal compressor is a radial turbomachine, which compresses air or gas with the action of centrifugal force. During the Second World War, the centrifugal compressors were used by British and American fighter aircrafts, as a part of early development of gas turbine engines. Later, during the 1950s, a large number of turboprop, turbofan, turbo-shafts and auxiliary power units started using the centrifugal compressors for air compression due to their high pressure raising capability in a single stage and their robustness in case of foreign object damage.

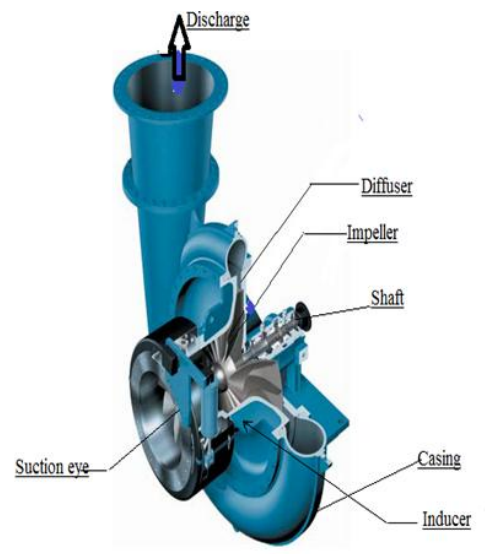

Figure.1. Basic Component of centrifugal compressor

Centrifugal compressors are a key piece of equipment for modern production. Among the components of the centrifugal compressor, the impeller is a pivotal part as it is used to transform kinetic energy into pressure energy. Impeller is an active part that adds energy to the fluid, its geometry plays a major role in the centrifugal compressors performance. An impeller is a wheel or rotor which is provided with a series of backward curved blades or vanes. It is mounted on a shaft which is couple to on external source of energy which imparts the required energy to the impeller there by making it to the rotate. The impellers may be classified as;

-Shrouded or closed impeller,

-Semi-open impeller and

-Open impeller.

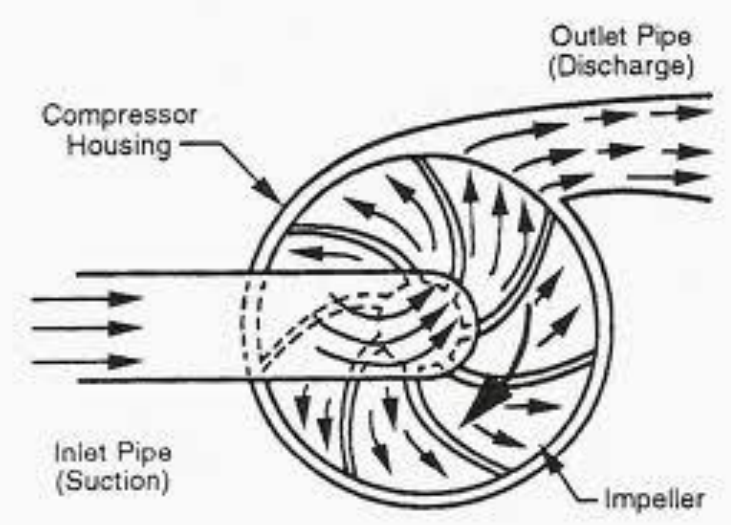

Figure.2. Working Principle of centrifugal compressor

\section{SPECIFICATION DATA}

$$
\begin{aligned}
& \text { Inlet pressure, } \mathrm{P}_{1}=1030.765 \mathrm{kPa} \\
& \text { Inlet temperature, } \mathrm{T}_{1}=380 \mathrm{~K} \\
& \text { Rated speed, } \mathrm{N}=45561 \mathrm{rpm} \\
& \text { Outlet pressure, } \mathrm{P}_{2}=1799.6 \mathrm{kPa} \\
& \text { Outlet temperature, } \mathrm{T}_{2}=448 \mathrm{~K} \\
& \text { Capacity, } \mathrm{Q}=0.1275 \mathrm{~m}^{3} / \mathrm{s} \\
& \text { Air mass flow rate, } \stackrel{\circ}{\mathrm{m}}=1.5907 \mathrm{~kg} / \mathrm{s}
\end{aligned}
$$

Centrifugal compressor with this specifications has been installed on Ahlone Power Station at Ahlone Township, Yangon, Myanmar. 


\section{METHODOLOGY}

The understanding of compressor operation is the ideal gas law, which is expressed in equation from the follows;

$$
\mathrm{Pv}=\mathrm{ZRT}
$$

The general form of the thermodynamic head equation for a polytropic process is

$$
\mathrm{H}_{\mathrm{p}}=\mathrm{ZRT}_{1} \frac{\mathrm{n}}{\mathrm{n}-1}\left[\left(\mathrm{r}_{\mathrm{p}}\right)^{\frac{\mathrm{n}-1}{\mathrm{n}}}-1\right]
$$

This equation drives from integrating the steady-state, steady flow work equation given by:

$$
\mathrm{H}_{\mathrm{p}}=\int \mathrm{vdp}
$$

The polytropic process is of form:

$$
\mathrm{Pv}^{\mathrm{n}}=\text { constant }
$$

\subsection{Impeller Inlet Dimension}

$$
\mathrm{D}_{\mathrm{S}}=\sqrt[3]{\frac{16 \mathrm{~T}}{\pi \mathrm{S}_{\mathrm{S}}}}
$$

The eye diameter Do may be found from the continuity equation:

$$
\begin{gathered}
\frac{\pi}{4} \mathrm{D}_{\mathrm{o}}^{2}-\frac{\pi}{4} \mathrm{D}_{\mathrm{h}}^{2}=\frac{\mathrm{Q}}{\mathrm{V}_{\mathrm{o}}} \\
\mathrm{D}_{\mathrm{O}}=\sqrt{\frac{4 \times \mathrm{Q}}{\pi \times \mathrm{V}_{\mathrm{O}}}+\mathrm{D}_{\mathrm{h}}^{2}}
\end{gathered}
$$

The mean diameter of the vane inlet is made slightly greater than the impeller eye diameter.

Speed of sound of gas, a

$$
\mathrm{a}=\sqrt{\mathrm{k} \times \mathrm{g} \times \mathrm{R} \times \mathrm{T}_{1}}
$$

The impeller inlet hub Mach number is 0.2 to 1 for compressible fluid. The value of Mach number is 0.3 (assumed).

The impeller absolute velocity equation is

$$
\mathrm{V}_{\mathrm{O}}=\mathrm{M} \times \mathrm{a}
$$

The air enters the impeller eye to tip in the axial direction and prewhirl angle is zero, so that $\mathrm{V}_{1}=\mathrm{V}_{\mathrm{fl}}$ and is made slightly greater than $\mathrm{V}_{\mathrm{o}}$.

Impeller inlet width, $\mathrm{b}_{1}$

$$
\mathrm{b}_{1}=\frac{\mathrm{Q}}{\pi \times \mathrm{V}_{1} \times \mathrm{D}_{1} \times \varepsilon_{1}}
$$

Impeller inlet velocity, $\mathrm{U}_{1}$

$$
\mathrm{U}_{1}=\frac{\pi \mathrm{D}_{1} \mathrm{~N}}{60}
$$

\subsection{Impeller Inlet Dimension}

Impeller Outlet diameter, $\mathrm{D}_{2}$

$$
\mathrm{D}_{2}=\frac{60 \times \sqrt{\mathrm{H}_{\mathrm{p}} \times \mathrm{g}}}{\pi \times \mathrm{n} \times \sqrt{\mathrm{K}^{\prime}}}
$$

Therefore

$$
\mathrm{V}_{\mathrm{f} 2}=\mathrm{V}_{\mathrm{f} 1}
$$

The outlet width is expressed by the following equation,

$$
\mathrm{b}_{2}=\frac{\mathrm{Q}}{\pi \times \mathrm{V}_{2} \times \mathrm{D}_{2} \times \varepsilon_{2}}
$$

The outlet vane thickness factor $\varepsilon_{2}$ can be calculated with following equation;

$$
\varepsilon_{2}=\frac{\pi \times \mathrm{D}_{2}-\frac{\mathrm{z} \times \mathrm{t}}{\sin \beta_{2}}}{\pi \times \mathrm{D}_{2}}
$$

\subsection{Enthalpy and Efficiency}

The greater the number of vanes, the smaller the slip, i.e. the more nearly V $\omega 2$ approaches U2. It is necessary in design to assume a value for the slip factor $\sigma$;

$$
\sigma=\frac{\mathrm{V}_{\omega 2}}{\mathrm{U}_{2}}
$$

To find the number of number of blades, the following equation is used.

$$
\sigma=1-\frac{0.63 \pi}{\mathrm{z}}
$$

A relation between $\mathrm{h}$ and $\mathrm{T}$, the most general form of $\mathrm{h}$ as $\mathrm{h}=\mathrm{h}(\mathrm{p}, \mathrm{T})$, then

$$
\mathrm{dh}=\left(\frac{\partial \mathrm{h}}{\partial \mathrm{T}}\right)_{\mathrm{p}} \mathrm{dT}+\left(\frac{\partial \mathrm{h}}{\partial \mathrm{p}}\right)_{\mathrm{T}} \mathrm{dp}
$$

Since the specific heat at constant pressure is defined as

$$
\begin{aligned}
& \mathrm{c}_{\mathrm{p}}=\left(\frac{\partial \mathrm{h}}{\partial \mathrm{T}}\right)_{\mathrm{p}} \text {,then } \\
& \mathrm{dh}=\mathrm{c}_{\mathrm{p}} \mathrm{dT}+\left(\frac{\partial \mathrm{h}}{\partial \mathrm{T}}\right)_{\mathrm{p}} \mathrm{dp}
\end{aligned}
$$

An ideal gas $\mathrm{h}$ is a function of $\mathrm{T}$ only.

Consequently, $\left(\frac{\partial \mathrm{h}}{\partial \mathrm{p}}\right)_{\mathrm{T}}=0$ and 


$$
\mathrm{dh}=\mathrm{c}_{\mathrm{p}} \mathrm{dT}
$$

The efficiency defined on the basic of this ideal work is the compressor efficiency.

$\eta_{\mathrm{c}}=$ ideal work between the stagnation states/actual work

$$
\eta_{\mathrm{c}}=\frac{\mathrm{h}_{02 \mathrm{~s}}-\mathrm{h}_{01}}{\mathrm{~h}_{02}-\mathrm{h}_{01}}
$$

Inlet blade angle, $\beta_{1}$

$$
\beta_{1}=\tan ^{-1} \frac{\mathrm{V}_{1}}{\mathrm{U}_{1}}
$$

Outlet blade angle, $\beta_{2}$

The compressor industry commonly uses a backward leading blade with angle, $\beta_{2}$ of between about 55-75 deg. The blade outlet angle of $75 \mathrm{deg}$ is maximum power position.

Therefore, the maximum design condition the outlet blade angle, $\beta_{2}=75 \mathrm{deg}$.

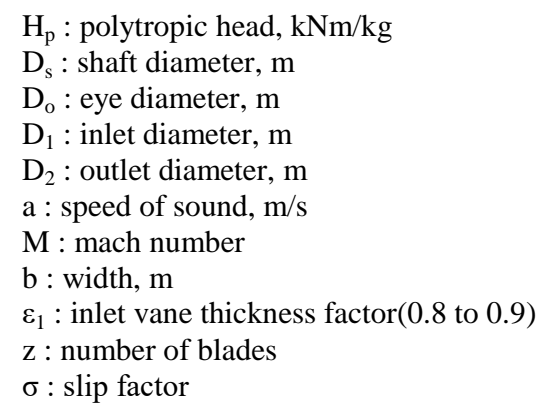

\section{VALUE OF MACH NUMBER}

The analytical design of impeller inlet result data are expressed by graphs.

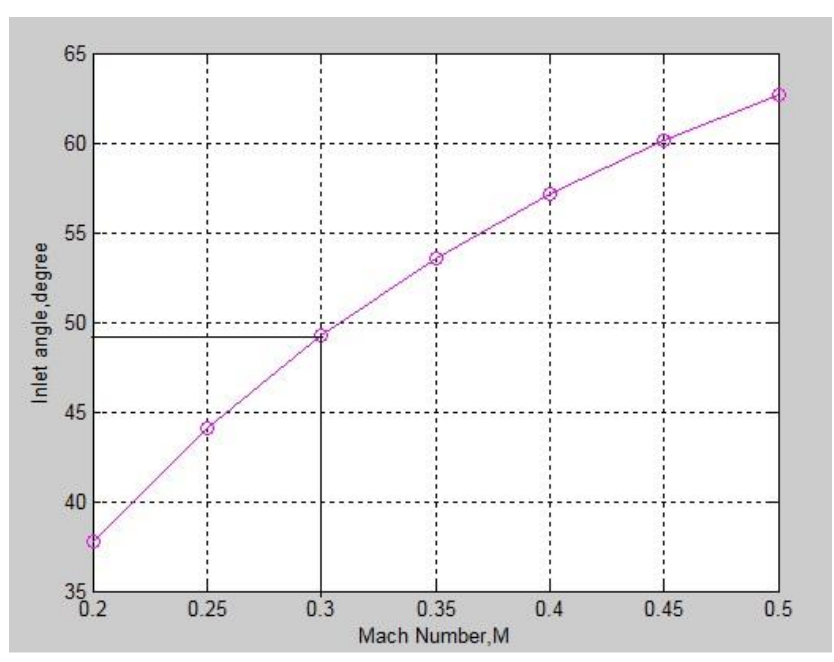

Figure.3. Mach number and Blade inlet angle

The relation between the blade inlet angle and Mach number are illustrated in Fig 2. This graph shows the larger the blade inlet angle, the higher the Mach number.

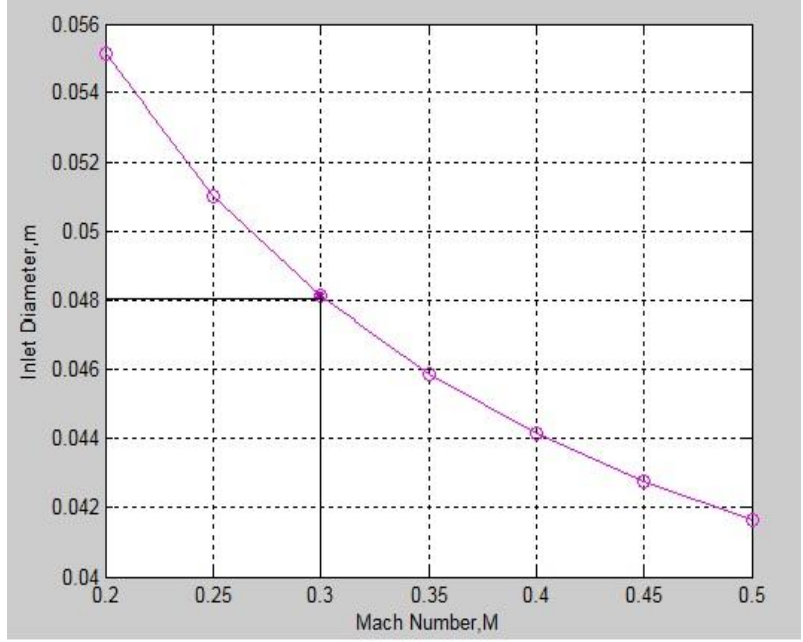

Figure.4. Mach number and Inlet diameter

The relation between the inlet diameter and Mach number are illustrated in Fig 3. This graph shows the smaller the inlet diameter, the higher the Mach number.

Based on these conditions Mach number, $\mathrm{M}$ is 0.3 , at that point of data is nearly equal to the actual of the centrifugal compressor impeller inlet. Therefore, the design is satisfied for at that point of data.

\section{THEORETICAL RESULTS}

TABLE I

CALCULATED DATA OF IMPELLER

\begin{tabular}{|l|l|l|l|l|}
\hline \multicolumn{1}{|c|}{ no } & Design Parameter & Symbol & \multicolumn{1}{|c|}{ Values } & \multicolumn{1}{|c|}{ Units } \\
\hline 1 & Polytropic head & $\mathrm{H}_{\mathrm{p}}$ & 67.411 & $\mathrm{kNm} / \mathrm{kg}$ \\
\hline 2 & Torque & $\mathrm{T}$ & 32.906 & $\mathrm{~N}-\mathrm{m}$ \\
\hline 3 & Speed of sound & $\mathrm{a}$ & 390.221 & $\mathrm{~m} / \mathrm{s}$ \\
\hline 4 & Mach number & $\mathrm{M}_{1}$ & 0.3 & - \\
\hline 5 & Inlet velocity & $\mathrm{U}_{1}$ & 103.283 & $\mathrm{~m} / \mathrm{s}$ \\
\hline 6 & $\begin{array}{l}\text { Absolute velocity } \\
\text { at inlet }\end{array}$ & $\mathrm{V}_{1}$ & 119.993 & $\mathrm{~m} / \mathrm{s}$ \\
\hline 7 & $\begin{array}{l}\text { Relative velocity } \\
\text { at inlet }\end{array}$ & $\mathrm{V}_{\mathrm{r} 1}$ & 158.322 & $\mathrm{~m} / \mathrm{s}$ \\
\hline 8 & Inlet blade angle & $\beta_{1}$ & 49.5 & $\mathrm{deg}$ \\
\hline 9 & Outlet velocity & $\mathrm{U}_{2}$ & 346.22 & $\mathrm{~m} / \mathrm{s}$ \\
\hline 10 & $\begin{array}{l}\text { Absolute velocity } \\
\text { at outlet }\end{array}$ & $\mathrm{V}_{2}$ & 336.209 & $\mathrm{~m} / \mathrm{s}$ \\
\hline 11 & $\begin{array}{l}\text { Relative velocity } \\
\text { at outlet }\end{array}$ & $\mathrm{V}_{\mathrm{r} 2}$ & 124.226 & $\mathrm{~m} / \mathrm{s}$ \\
\hline 12 & $\begin{array}{l}\text { outlet blade angle } \\
n_{2}\end{array}$ & 75 & $\mathrm{deg}$ \\
\hline 13 & Outlet Mach no; & $\mathrm{M}_{2}$ & 0.8 & - \\
\hline 14 & efficiency & $\mathrm{n}$ & 94 & $\%$ \\
\hline
\end{tabular}


TABLE II

COMPARISON OF CALCULATED AND EXISTING DATA

\begin{tabular}{|c|c|c|c|c|c|}
\hline & $\begin{array}{c}\text { Design } \\
\text { Parameter }\end{array}$ & Symbol & Unit & $\begin{array}{c}\text { Calculated } \\
\text { data }\end{array}$ & $\begin{array}{c}\text { Actual } \\
\text { data }\end{array}$ \\
\hline 1 & $\begin{array}{c}\text { Shaft } \\
\text { diameter }\end{array}$ & $\mathrm{D}_{\mathrm{s}}$ & $\mathrm{m}$ & 0.02 & 0.0254 \\
\hline 2 & $\begin{array}{c}\text { Hub } \\
\text { diameter }\end{array}$ & $\overline{D_{h}}$ & $\mathrm{~m}$ & 0.0225 & 0.028 \\
\hline 3 & $\begin{array}{c}\text { Eye } \\
\text { diameter }\end{array}$ & $\mathrm{D}_{\mathrm{o}}$ & $\mathrm{m}$ & 0.047 & 0.053 \\
\hline 4 & $\begin{array}{c}\text { Inlet } \\
\text { diameter }\end{array}$ & $\mathrm{D}_{1}$ & $\mathrm{~m}$ & 0.048 & 0.054 \\
\hline 5 & $\begin{array}{c}\text { Outlet } \\
\text { diameter }\end{array}$ & $\mathrm{D}_{2}$ & $\mathrm{~m}$ & 0.161 & 0.17 \\
\hline 6 & Inlet width & $b_{1}$ & $\mathrm{~m}$ & 0.009 & 0.0098 \\
\hline 7 & $\begin{array}{l}\text { Outlet } \\
\text { width }\end{array}$ & $b_{2}$ & $\mathrm{~m}$ & 0.0021 & 0.0025 \\
\hline 8 & $\begin{array}{c}\text { Number of } \\
\text { vanes }\end{array}$ & Z & - & 19 & 19 \\
\hline
\end{tabular}

The design of impeller in this paper is calculated inlet and outlet diameters and blade width and number of blades. The designed data of impeller inlet in this research are as well as the shaft diameter $D_{s}$ is $0.02 m$, the hub diameter $D_{h}$ is $0.0225 \mathrm{~m}$, Eye diameter $D_{0}$ is $0.047 \mathrm{~m}$, Impeller inlet diameter $\mathrm{D}_{1}$ is $0.048 \mathrm{~m}$, Impeller outlet diameter $\mathrm{D}_{2}$ is $0.161 \mathrm{~m}$, Inlet width $b_{1}$ is $0.009 \mathrm{~m}$, Outlet width $b_{2}$ is $0.0021 \mathrm{~m}$. All of the calculated data are slightly smaller than the actual data. This calculated data can be accepted because this data are situated between $20 \%$ error. The number of impeller blade is same at these two data.

\section{CONCLUSIONS}

Centrifugal compressors are compressible flow machine. Centrifugal compressor from 'Ahlone Power Station' is designed in this paper. This paper is attempted to design a single stage centrifugal compressor from 'Ahlone Power Station'. The design of impeller in this paper is inlet and outlet diameter and number of blades and blade width. This paper describes the inlet and outlet velocity triangle. And this research shows the pressure and velocity distribution by using COMSOL Multiphysics software.
Types of compressor are used in many services and power generation. Centrifugal compressors compress air to raise pressure at high speed. This compressor use also main component in aircraft gas turbine. In this paper, the centrifugal compressor is designed with data from 'Ahlone Power Station'.

\section{REFERENCES}

[1] Balije, O.E: Turbomachines. New York: John Wiley and Sons, Inc., 1981.

[2] Ronald P. Lapina P>E. Estimating Centrifugal Compressor Performance Process compressor thchnology. Vol-1. McGraw Hill Publications Co,1982

[3] Ebara Hatakeyama Memorial Fund: Compressor Engineering. U.S.A. John Wiley and Sons, Inc., 1992.

[4] Meherwan, P. Boyce: Gas Turbine Engineering Handbooks, Part-II. $2^{\text {nd }}$.Ed., New Delhi: Gulf Professional Publishing Co.,2002.

[5] Rama S.R.Gorla, Turbomachinary Design and Theory,Cleveland State University,Cleveland,Ohio, U.S.A 2003.

[6] Beckers, J.: Uses of High-Speed Turbocompressors in Offshore Installations.

[7] Woodhouse, H., Inlet Conditions of Centrifugal Compressor for Aircraft Engine Superchargers and Gas Turbines, 2006 